\title{
4. CURRENT SITUATION IN THE DYNAMICS OF GENERAL EDUCATION IN THE REPUBLIC OF MOLDOVA
}

\begin{abstract}
Viorica Crișciuc ${ }^{251}$
Abstract: Currently, the education system in the Republic of Moldova is in a specific political, economic, value, demographic context and is periodically influenced by external factors: globalization, internationalization, computerization, etc. At the same time, there are continuous changes in the education system at the level of educational policies, in accordance with the political system of the Republic of Moldova: decentralization of managerial functions, financing the system per student, reconstruction of networks of educational institutions, resizing continuous training of managers and teachers. Through the reforms launched during 2009-2020 by the Ministry of Education, Culture and Research of the Republic of Moldova, in cooperation with development partners, they changed their emphasis in education in favor of quality and, respectively, the process of evaluating student results. Updating the National Curriculum made in accordance with the fundamental support Reference framework of the National Curriculum, Basic Curriculum: competency system for general education, analytical support School curriculum evaluation report, etc. and the managerial support provided by the Ministry of Education, Culture and Research of the Republic of Moldova, favored a modern educational system with obvious results in national evaluations.
\end{abstract}

Key words: the education system, globalization, internationalization, computerization, results in national evaluations

\section{Introduction}

Through the reforms launched during 2009-2020 by the Ministry of Education, Culture and Research of the Republic of Moldova, in cooperation with development partners, they changed their emphasis in education in favor of quality and, respectively, the process of evaluating student results. Updating the National Curriculum made in accordance with the fundamental support Reference framework of the National Curriculum, Basic Curriculum: competency system for general education, analytical support School curriculum evaluation report, etc. and the managerial support provided by the Ministry of Education, Culture and Research of the Republic of Moldova, favored a modern educational system with obvious results in national evaluations.

The fact that the Republic of Moldova already has experience in three PISA evaluations $(2009+, 2015,2018)$ allows the realization of analytical and comparative studies of students' results; determining the internal and external indicators, which favored the increase or decrease of the students' results in relation to the characteristics of the school (high school, small school); the locality in which it is located; respectively, different results by gender (boys, girls); correlating the connection between life satisfaction; students' attitudes and educational achievements in the Republic of Moldova. In three out of five

\footnotetext{
251 Associate Professor PhD., „Alecu Russo” State University from Bălţi, Republic of Moldavia, email: vioricacrisciuc@gmail.com
} 
educational institutions in the Republic of Moldova, the teaching-learningassessment process is affected by the lack of teachers and educational materials.

\section{Discussions}

Teachers are the most important resource of today's educational institutions. Many countries are trying to attract more people to the teaching profession not only to avoid teacher shortages, but also to expand teachers' knowledge and experiences, increasing the capacity of the education system to cope with student diversity.

An education system without highly qualified teachers will perform poorly compared to other systems. According to PISA 2018 data, in about 35\% of the number of educational institutions in the Republic of Moldova the teaching process is affected by the lack of teachers. Compared to OECD countries, this figure is 7 percentage points higher. At the same time, rural educational institutions are affected by the lack of teaching staff more than urban ones. About $38 \%$ of the number of principals of rural educational institutions and $27 \%$ of the number of principals of urban educational institutions reported facing this problem. However, the quality of teaching staff in the Republic of Moldova does not seem to be as big an issue as the lack of teaching staff. SOURCE: PISA 2018 Results Program for International Student Assessment

The quality of training in the Romanian language and literature discipline.

In the PISA 2018 questionnaires, students were asked to what extent: clear goals for streamlining learning in the language of instruction; close monitoring of the evolution of learning outcomes; the appropriate pace and management of the situation in the classroom; clarity of presentation of learning contents, wellstructured lessons and comments during the lessons that inform and encourage the student; were present at the lessons. According to the results of the survey, $89 \%$ of students reported that the Romanian / Russian language and literature teacher sets clear goals for their learning, compared to $72 \%$ of students in OECD countries who reported the same. About $65 \%$ of the number of students said that at the beginning of each lesson the teacher recapitulates what they learned in the previous lessons (the percentage refers to those students who answered: "most lessons" or "each lesson"). About 63\% of the number of students in the Republic of Moldova consider that their teachers offer individual help when there are difficulties in understanding a topic or a task, while, on average, in OECD countries, about $54 \%$ of the number of students reported the same situation.

\section{Results}

Significant progress has been made in achieving the goal of ensuring that all students reach the minimum level of reading / reading competence, but the percentage of those with low results is high ...In the field that was emphasized in PISA 2018 - reading / reading, the performance of 15-year-olds in the Republic of Moldova increased compared to 2009, when the field of reading / reading was also the basic area in the evaluation of PISA. During the last decade, the Republic of Moldova has made progress in achieving the goal of ensuring that all students reach the minimum level of proficiency in reading / reading. 
The results of PISA 2018 show that the Republic of Moldova is among the four countries in the world, which have managed to reduce the percentage of students who do not reach the minimum level of competence, by more than 10 percentage points. However, about $43 \%$ of the number of students in the Republic of Moldova do not reach the minimum level of reading / reading competence. A significant difference in the percentage of students who do not achieve the minimum level of competence in PISA is attested among students in urban and rural educational institutions. When reading / reading about $30 \%$ of the number of students in urban educational institutions are below the basic level of competence, then among students in rural educational institutions this percentage is about double (58\% of the number of low-performing students when reading / reading).

The number of teachers is also decreasing due to the decrease in the number of students in the field of Education Sciences. Their number decreases every year, so that in 2015 there were 2523 students in this field, and in 2018 the number reached 1725. Therefore, ensuring the equity, the quality of resources invested in education from the perspective of the quality of training in the education system of the Republic of Moldova, must continue to be oriented towards:

1. Increasing the attractiveness of the teaching profession in order to encourage young people to embrace this profession;

2. Maintaining qualified teachers in the educational system.

In this context, we note the gap in the number of students enrolled in national exams, which is decreasing due to the demographic situation in the country. The figure shows the information on the number of candidates for high school graduation exams for 2017-2019.

Figure 1. Number of candidates evaluated at the high school graduation exam

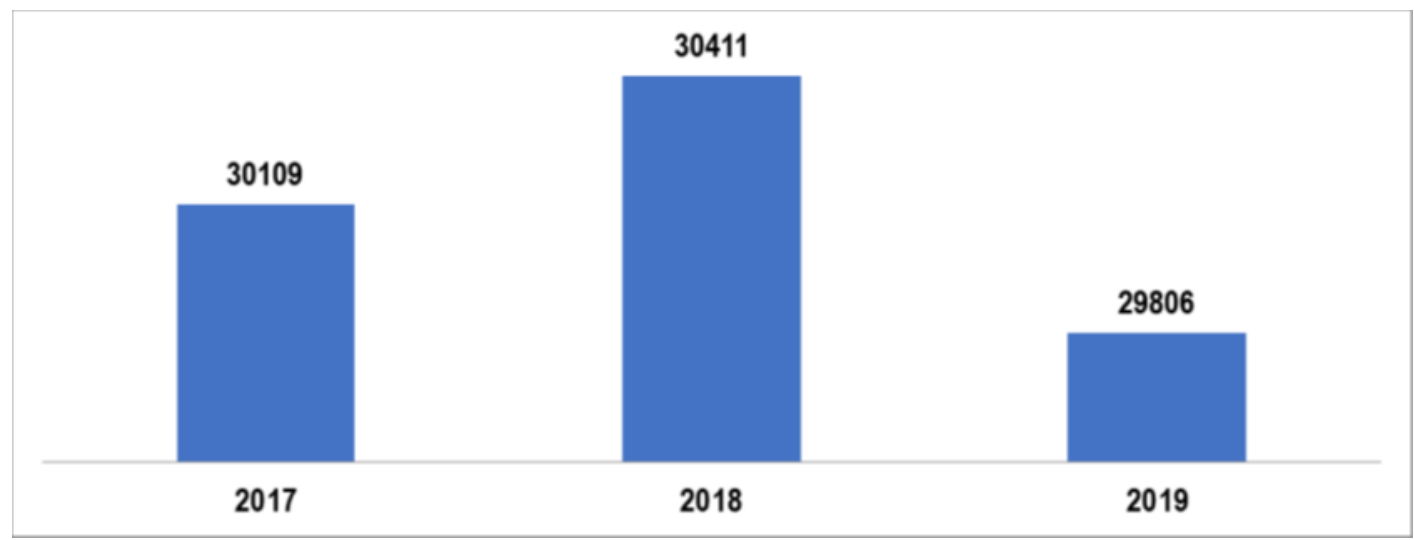

In this order of ideas, for comparison, about $40.1 \%$ of high schools had less than 25 candidates. It is found that in many schools the number of students who completed high school in 2019 is low: of the 289 theoretical high schools, 52 had no more than 15 students, 64 had between 16 and 25 students, 111 had between 26 and 50 students and only 9 had over 90 students. The figure below shows the averages of the grades at the high school graduation exams in the 2017-2019 sessions. 
Figure 2. Grade averages at the high school graduation exams in the 2017-2019 sessions

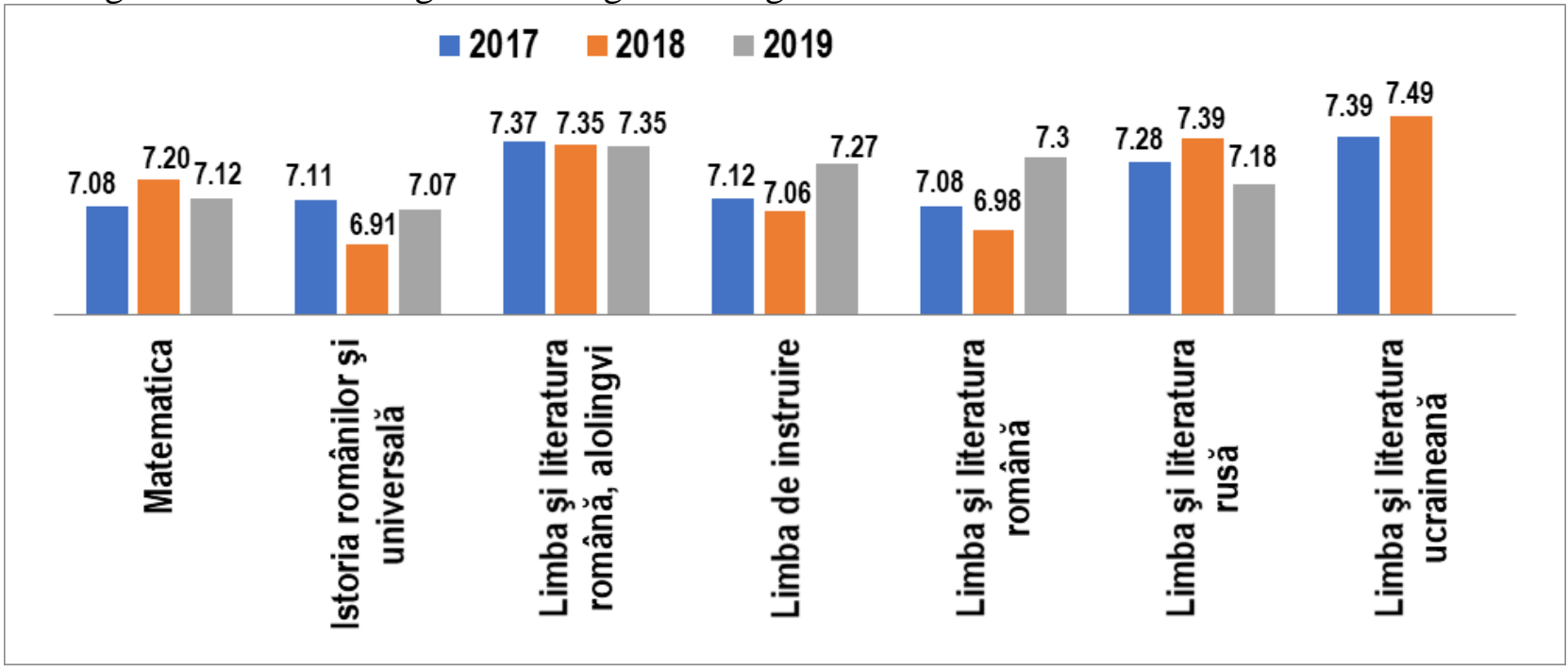

\section{Conclusions}

1. The results of the survey of students, teachers, managers of PISA institutions are open, provide relevant data on the quality of training in the subjects evaluated, equipping educational institutions with educational materials, provide transparency and access to information on the relationship among the educational, financial, material and human resources, and the performances of the students from the Republic of Moldova.

2. The situation of general education in the Republic of Moldova is marked by progress at the national level, as well as by a series of regressions at the international level. Currently, the Ministry of Education, Research and Culture is looking for solutions to close the gaps in the process of implementation, modernization, development of reforms. The existing legislation in the field of general education was amended and supplemented, new legislative and normative acts were elaborated. Education has been declared a national priority at the level of legislation, a series of programs and strategies are developed that aim to modernize education at all levels of schooling (preschool education, pre-university education, vocational secondary education, etc.).

3. Modern educational policies are continuously implemented in the Republic of Moldova. In dynamics, the general education of the Republic of Moldova attests qualitative changes at the level of educational policies, which provide: decentralization of managerial functions, optimization of networks of educational institutions, resizing the continuous training of managerial and teaching staff, etc. The reforms launched during 2009-2020 by the Ministry of Education, Culture and Research of the Republic of Moldova, change the emphasis in education in favor of quality and, respectively, the evaluation of students' results.

4. There are fewer teachers in the education system than is needed, but in urban areas the situation is better than in rural areas. The teacher / student ratio, although increasing, is still optimal (1/12). 


\section{References}

1. Codul Educației al Republicii Moldova, Chișinău 2014, nr.152 din 17.07.2014, Monitorul Oficial al Republicii Moldova, nr.319 - 324, art.nr.614 din 23.11.2014 2. Crișciuc, V., Gagim I., (2016) ,Teoria și metodologia predării cunoștințelor muzicale, Studiu monografic. Univ. de Stat „Alecu Russo” din Bălți. - Chișinău: Pontos, p.342, ISBN 978-876-64-53-2

3. Kabalevskii, D., (1987) Cultivarea cugetului şi sufletului, Chişinău: Lumina, $121 \mathrm{p}$

4. Metodologia privind implementarea evaluării criteriale prin descriptori (ediția a II-a, actualizată și completată) (ed. I apr. la Cons. Naț. pentru Curriculum, Ord. ME nr. 862 din 07 sept. 2015; ediția a II-a apr. la Consiliul Științifico-Didactic al IȘE din 27.12.2017)

5. Manolescu, I., (2011), Evaluarea în educație meritocrația și mediocritatea, București: Editura universitară, p.155, ISBN 965-676-34-52-3

6. Raport PISA 2018, www.oecd.org.com

7. http://www.oecd.org/document/61/0,3746,en_32252351_32235731_46567613_ 1_1_1_1,00.html

8. http://www.oecd.org/document/19/0,3746,en_2649_35845621_48577747_1_1_ $1 \_1,00 . h t m l$

9. http://www.oecd-ilibrary.org/education/pisa-data-analysis-manual-sas-seconddition_9789264056251-en

10. Strategia pentru asigurarea egalității între femei și bărbați în Republica Moldova pe anii 2016-2020 http://www.particip.gov.md/public/documente/139/ro_3140_anexa1.pdf 11. https://www.soros.md/files/Studiu\%20Cristei\%20Aliona\%202017-09-29.pdf 